University of New Hampshire

University of New Hampshire Scholars' Repository

Faculty Publications

8-28-2015

\title{
Removal of terrestrial DOC in aquatic ecosystems of a temperate river network
}

\author{
Wilfred M. Wollheim \\ University of New Hampshire, Durham, wil.wollheim@unh.edu \\ Robert J. Stewart \\ University of New Hampshire, Durham, Rob.Stewart@unh.edu \\ G. R. Aiken \\ United States Geological Survey \\ K. D. Butler \\ United States Geological Survey
}

N. B. Morse

University of New Hampshire, Durham

See next page for additional authors

Follow this and additional works at: https://scholars.unh.edu/faculty_pubs

Comments

This is an article published by AGU in Geophysical Research Letters in 2015, available online: https://dx.doi.org/

10.1002/2015GL064647

\section{Recommended Citation \\ Wollheim, W.M., R.J. Stewart, G.R. Aiken, K.D. Butler, N.B. Morse, and J. Salisbury. 2015. Removal of terrestrial dissolved organic carbon in aquatic ecosystems of a temperate river network. Geophysical Research Letters. 42, doi:10.1002/2015GL064647}

This Article is brought to you for free and open access by University of New Hampshire Scholars' Repository. It has been accepted for inclusion in Faculty Publications by an authorized administrator of University of New Hampshire Scholars' Repository. For more information, please contact Scholarly.Communication@unh.edu. 


\section{Authors}

Wilfred M. Wollheim, Robert J. Stewart, G. R. Aiken, K. D. Butler, N. B. Morse, and Joseph E. Salisbury 


\section{Geophysical Research Letters}

\section{RESEARCH LETTER}

10.1002/2015GL064647

Key Points:

- Low net removal of terrestrial DOC during transport through river networks

- HPOA is removed more rapidly than other terrestrial DOC forms

- Findings contrast with DOC reactivity measured during other studies

Supporting Information:

- Text S1, Figures S1 to S3, and Table S1

Correspondence to:

W. M. Wollheim,

wil.wollheim@unh.edu

\section{Citation:}

Wollheim, W. M., R. J. Stewart, G. R. Aiken, K. D. Butler, N. B. Morse, and J. Salisbury (2015), Removal of terrestrial DOC in aquatic ecosystems of a temperate river network, Geophys. Res. Lett., 42, 6671-6679, doi:10.1002/2015GL064647.

Received 19 JUN 2015 Accepted 28 JUL 2015 Accepted article online 29 JUL 2015 Published online 19 AUG 2015

\section{Removal of terrestrial DOC in aquatic ecosystems of a temperate river network}

\author{
W. M. Wollheim ${ }^{1,2}$, R. J. Stewart ${ }^{1,2}$, G. R. Aiken ${ }^{3}$, K. D. Butler ${ }^{3}$, N. B. Morse ${ }^{1,2}$, and J. Salisbury ${ }^{4}$ \\ ${ }^{1}$ Department of Natural Resources and Environment, University of New Hampshire, Durham, New Hampshire, USA, ${ }^{2}$ Earth \\ Systems Research Center, University of New Hampshire, Durham, New Hamsphire, USA, ${ }^{3}$ United States Geological Survey, \\ Boulder, Colorado, USA, ${ }^{4}$ Ocean Process Analysis Laboratory, University of New Hampshire, Durham, New Hampshire, USA
}

Abstract Surface waters play a potentially important role in the global carbon balance. Dissolved organic carbon (DOC) fluxes are a major transfer of terrestrial carbon to river systems, and the fate of DOC in aquatic systems is poorly constrained. We used a unique combination of spatially distributed sampling of three DOC fractions throughout a river network and modeling to quantify the net removal of terrestrial DOC during a summer base flow period. We found that aquatic reactivity of terrestrial DOC leading to net loss is low, closer to conservative chloride than to reactive nitrogen. Net removal occurred mainly from the hydrophobic organic acid fraction, while hydrophilic and transphilic acids showed no net change, indicating that partitioning of bulk DOC into different fractions is critical for understanding terrestrial DOC removal. These findings suggest that river systems may have only a modest ability to alter the amounts of terrestrial DOC delivered to coastal zones.

\section{Introduction}

The flux of terrestrially derived carbon from aquatic ecosystems back to the atmosphere is potentially an important term in the global carbon cycle [Battin et al., 2008; Cole et al., 2007]. While much of this return flux is of degassing inorganic carbon derived from terrestrial respiration or weathering [Finlay, 2002; Johnson et al., 2008; Richey et al., 2002], aquatic respiration of terrestrial organic carbon may also play an important role [AufdenKampe et al., 2011; Cole and Caraco, 2001]. Dissolved organic carbon (DOC) is the major form of organic carbon transported by river systems. Numerous studies using incubations and in situ carbon additions indicate that DOC can be highly reactive [Newbold et al., 2006; Cory and Kaplan, 2012] implying that aquatic fluxes may be considerably altered by aquatic processes. However, in situ estimates of carbon uptake rates can vary considerably in time and space due to the diversity of molecules [Bernhardt and McDowell, 2008; Newbold et al., 2006]. The net transformation of DOC throughout river systems is therefore difficult to quantify. Further, it is difficult to assess the fate of DOC in situ because losses may be quickly balanced by new sources.

Measurement of DOC character offers the ability to further constrain DOC fate in river systems. Recent continental-scale empirical analyses of both bulk DOC and DOC character from large watersheds suggest little evidence of major transformation of terrestrial sources, unless long residence time lakes or reservoirs are present [Butman et al., 2012; Hanley et al., 2013]. The ability of large river sampling alone to identify net transformations is limited because the amount of DOC entering the river system of a watershed is unknown. One strategy is to hierarchically sample DOC quantity and character across a range of stream sizes and land use types synoptically [Kaushal et al., 2014; Agren et al., 2014; Tiwari et al., 2014] to determine whether net removal of terrestrial DOC by aquatic ecosystems is evident. However, these previous studies explored only bulk DOC changes, even though reactivity is highly variable among DOC forms [Kaplan et al., 2008; Cory and Kaplan, 2012].

Here we report the findings of a hierarchical sampling and river network model analysis to quantify net removal of terrestrial DOC as water flows from terrestrial systems through a medium-sized river network $\left(400 \mathrm{~km}^{2}\right)$. The study was conducted in the Ipswich River watershed, MA, USA, which drains part of suburban Boston, but also consists of abundant and heterogeneously distributed wetlands (Figure 1), which are a major source of DOC [Raymond and Hopkinson, 2003]. We quantified the net reactivity of bulk DOC and different DOC fractions relative to chloride, a conservative tracer, and nitrate, which is moderately reactive [Ensign and Doyle, 2006; Wollheim et al., 2008]. 


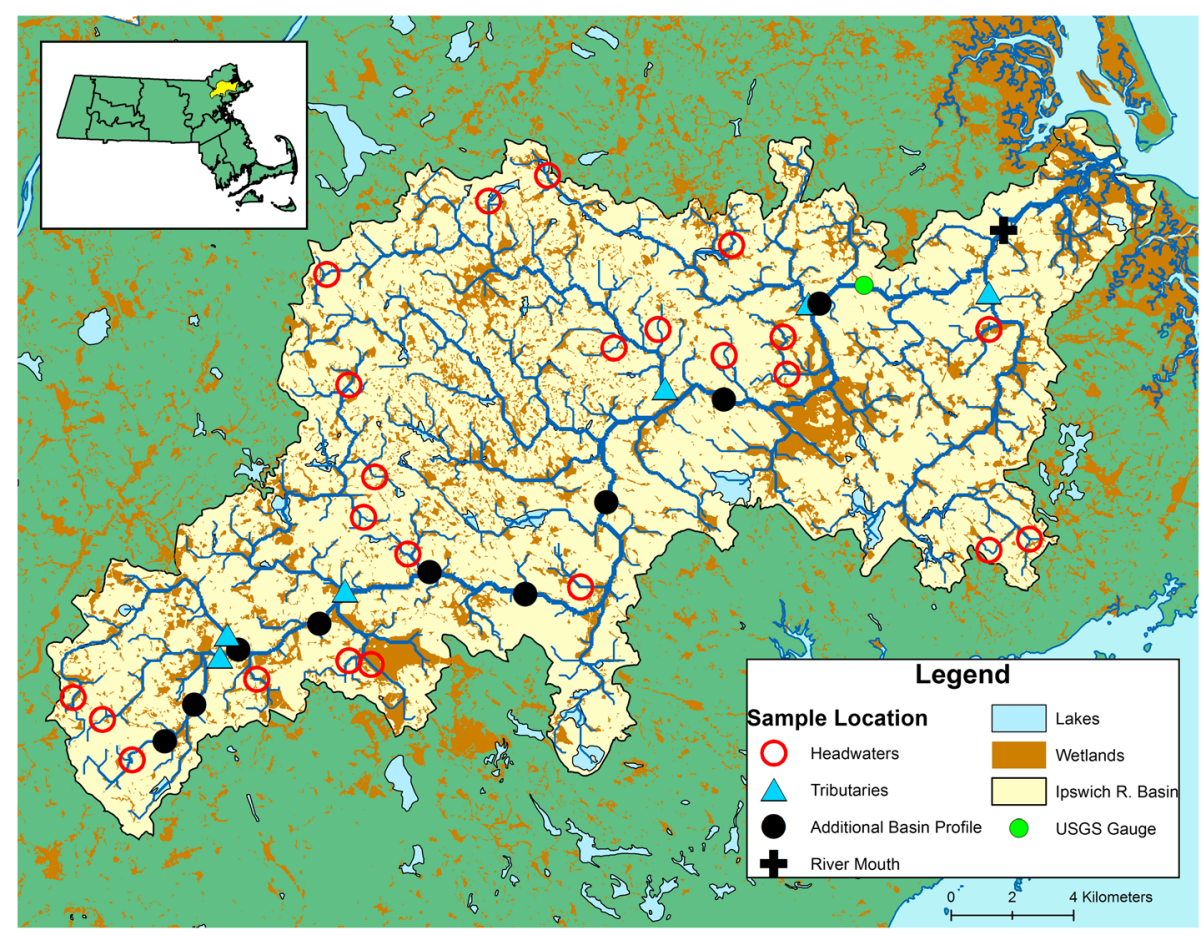

Figure 1. Map of the Ipswich River watershed showing river network, wetlands, and sample locations of different stream types.

\section{Methods}

We collected samples throughout the river network from headwaters to basin mouth during the July 2011 low flow period (Figure 1). Discharge (Q) at the U.S. Geological Survey (USGS) gage $(\operatorname{site}=01102000)$ averaged $1.7 \mathrm{~m}^{3} \mathrm{~s}^{-1}$ (34th percentile of long-term record). Samples were collected in headwater streams (drainage area $\left.<4 \mathrm{~km}^{2}, n=25\right)$, major tributaries $\left(10-50 \mathrm{~km}^{2}, n=6\right)$, the basin mouth $\left(400 \mathrm{~km}^{2}, n=1\right)$, and at additional sites along the river main stem $(n=8)$. At each site, we measured concentrations $\left(\mathrm{mg} \mathrm{L}^{-1}\right)$ of bulk DOC, chloride $\left(\mathrm{Cl}^{-}\right)$, and DIN $\left(\mathrm{NH}_{4}{ }^{+}+\mathrm{NO}_{3}{ }^{-}\right.$, predominately $\left.\mathrm{NO}_{3}{ }^{-}\right)$. At roughly half the sites, we measured specific UV absorbance at $\lambda 254 \mathrm{~nm}\left(\mathrm{SUVA}_{254}\right)$ and the percent of total DOC as hydrophobic organic acids (HPOA\%), hydrophilic compounds (HPI\%), and transphilic acids (TPIA\%) [Aiken et al., 1992; Weishaar et al., 2003] (supporting information). From DOC and HPOA\%, HPI\%, and TPIA\%, we derived concentrations of HPOA, HPI, and TPIA. For each of DOC, SUVA $254, \mathrm{HPOA}, \mathrm{HPI}, \mathrm{TPIA}, \mathrm{Cl}^{-}$, and DIN, we developed concentration versus land use relationships for headwater and tributary sites and compared these with measurements at the basin mouth. We used analysis of covariance (ANCOVA) to test whether land use regressions differed between headwaters and tributaries. Net aquatic removal would cause the regression parameters to differ, as would differences in loading directly to small versus large streams. Statistical analyses were conducted in $R$ [R Foundation for Statistical Computing, Austria, 2008].

We used a spatially distributed, river network modeling approach (the Framework for Aquatic Modeling in the Earth System (FrAMES)) [Stewart et al., 2011; Wollheim et al., 2008] to quantify constituent loading at the network scale and to estimate mean net removal parameters for DIN, $\mathrm{Cl}^{-}$, bulk DOC, HPOA, HPI, and TPIA. The model accounts for spatially distributed inputs to the river network from land, mixing/dilution, and net aquatic removal as constituents are routed downstream through a gridded river network. Horizontal transport is estimated from terrestrial runoff using a steady state flow accumulation approach. The network for the Ipswich has a grid resolution of $120 \mathrm{~m}$ [Wollheim et al., 2008] (supporting information). Each surface water grid cell contains a stream reach with dimensions predicted by local discharge and hydraulic equations, as described in Wollheim et al. [2008].

Simulated loads $\left(\mathrm{kg} \mathrm{d}^{-1}\right)$ of DIN, DOC, HPOA, HPI, TPIA, and $\mathrm{Cl}^{-}$to the river network were based on runoff depth, surface area, and estimated constituent concentrations for each grid cell. Runoff was derived from the USGS discharge gage during the synoptic survey and assumed spatially uniform during base flow 

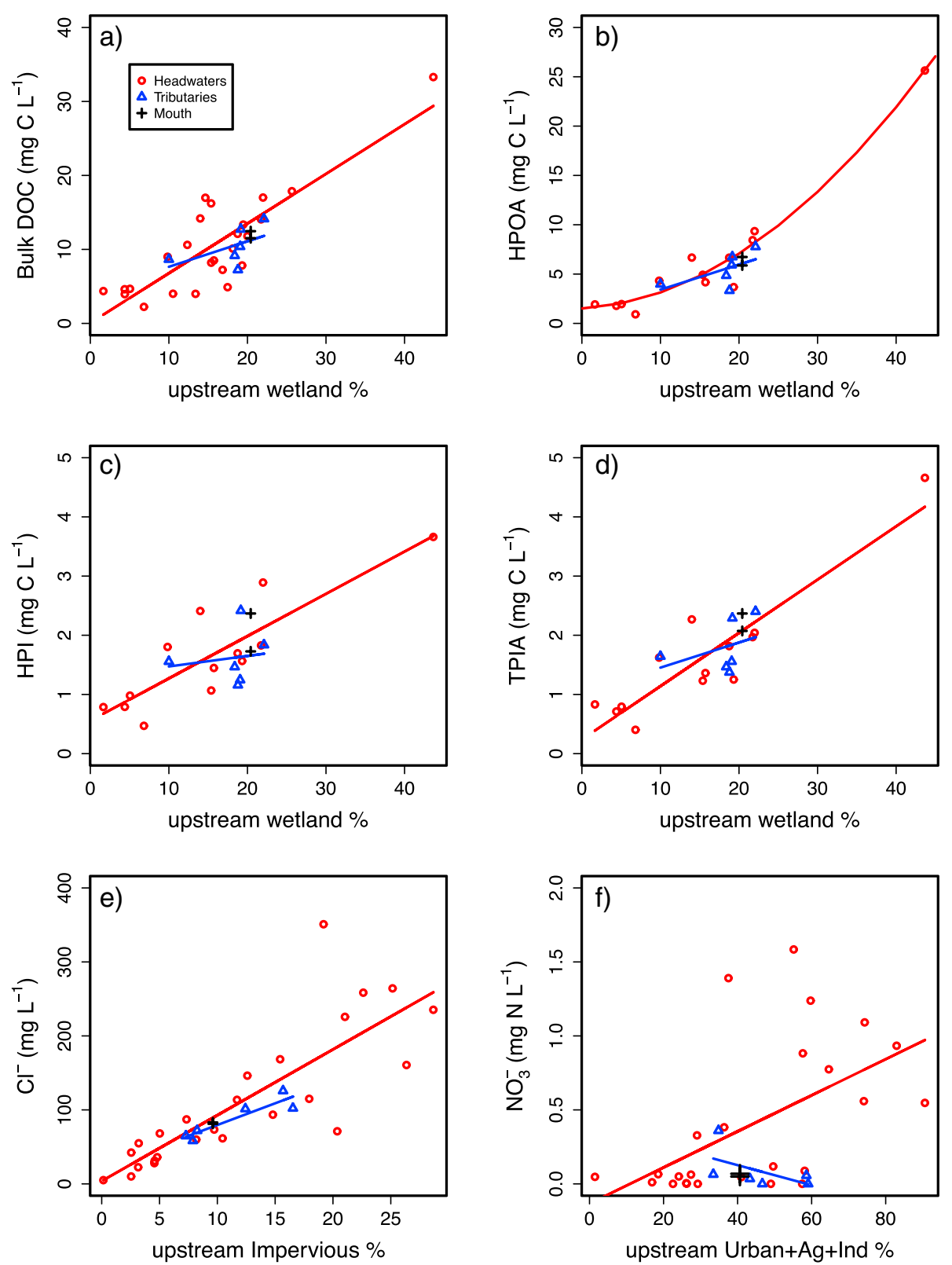

Figure 2. Relationship between upstream wetland\% and concentrations $\left(\mathrm{mg} \mathrm{L}^{-1}\right)$ of (a) bulk DOC, (b) HPOA, and (c) HPI, (d) TPIA, and (e) between upstream impervious $\%$ and $\mathrm{Cl}^{-}$, and (f) between upstream human land use $\%$ and $\mathrm{NO}_{3}{ }^{-}$for headwater catchments $\left(<5 \mathrm{~km}^{2}\right)$, major tributaries $\left(10-50 \mathrm{~km}^{2}\right)$, and the mouth of the basin $\left(400 \mathrm{~km}^{2}\right)$.

$\left(0.45 \mathrm{~mm} \mathrm{~d}^{-1}\right)$. Loading concentrations $\left(\mathrm{mg} \mathrm{L}^{-1}\right)$ were derived from relationships between observed stream concentrations and land cover in headwater catchments as described above (Figure 2):

$$
\begin{gathered}
\mathrm{DOC}_{\text {conc }}=0.065+0.67 \times \mathrm{Wet}+\varepsilon_{\mathrm{DOC}} \\
\mathrm{DIN}_{\text {conc }}=-0.016+0.012 \times \mathrm{Hum}+\varepsilon_{\mathrm{DIN}} \\
\mathrm{Cl}_{\text {conc }}=3.8+8.9 \times \mathrm{Imp}+\varepsilon_{\mathrm{Cl}} \\
\mathrm{HPOA}_{\text {conc }}=1.51+0.046 \times \mathrm{Wet}+0.012 \times \mathrm{Wet}^{2}+\varepsilon_{\mathrm{HPOA}} \\
\mathrm{HPI}_{\text {conc }}=0.554+0.0714 \times \mathrm{Wet}+\varepsilon_{\mathrm{HPI}} \\
\mathrm{TPIA}_{\text {conc }}=0.24+0.09 \times \mathrm{Wet}+\varepsilon_{\mathrm{TPIA}}
\end{gathered}
$$

where Wet, Hum, and Imp are percentages of wetlands, human (commercial + residential + agriculture), and impervious surfaces, and $\varepsilon_{X}$ are error terms calculated as the product of Gaussian random $z$ score and each 
constituents standard error of estimate (SEE), derived from residuals of each regression (Figure 2; supporting information). The entire watershed was partitioned into $2 \mathrm{~km}^{2}$ subbasins and equations (1)-(6) applied to each grid cell within based on the percent land use in the subbasin [as in Wollheim et al., 2008]. Subbasins (collections of grid cells) were used to assign loading concentrations because they are of a similar scale and land use variability as the sampled headwater basins. Gridded loading was determined to account for proper location of input along stream reaches. Most terrestrial runoff (78\% in this watershed) [Wollheim et al., 2008] and therefore terrestrial DOC enters the network through first- and second-order streams.

As loads are routed through the river network, net removal of each constituent by each river grid cell is calculated using the equation $R=1-\exp \left(-v_{f} / H_{L}\right)$, where $R$ is the proportion of incoming flux removed [-], $v_{f}$ is the uptake velocity leading to net removal $\left(\mathrm{m} \mathrm{yr}^{-1}\right)$, and $H_{L}$ is the hydraulic load $\left(\mathrm{m} \mathrm{yr}^{-1}\right)$ [Ensign and Doyle, 2006; Wollheim et al., 2008]. We assume that $v_{f}$ (length/time) is the appropriate reaction rate parameter to calibrate a network wide reaction rate as discussed elsewhere [Wollheim et al., 2006] (supporting information). $H_{L}$ is $Q /(W \times L) \times 365$, where $Q$ is the simulated river discharge as described above $\left(\mathrm{m}^{3} \mathrm{~d}^{-1}\right)$, and $W$ and $L$ are the simulated river width $(\mathrm{m})$ and length $(\mathrm{m})$. The mass $\left(\mathrm{kg} \mathrm{d}^{-1}\right)$ of each constituent removed is calculated by multiplying $R$ by the total mass entering the grid cell.

We estimated uncertainty in the predictions of loading to the network using a Monte Carlo analysis on 3000 unique spatially distributed loading scenarios, with each assuming a random error term $\left(\varepsilon_{X}\right)$ with Gaussian noise and zero mean derived from the residuals of the headwater loading relationships (equations (1)-(6)). For each loading scenario, we estimated the basin-wide net $v_{f}$ (i.e., representing an average throughout the network) that provides the best fit between observed and predicted concentrations along a longitudinal transect from the distant headwaters to the basin mouth (i.e., the basin profile) based on the Nash-Sutcliffe coefficient. We report the median and quartiles of $v_{f}$ for each constituent across all of the scenarios (see supporting information for further detail). Although a constant $v_{f}$ throughout the river network is unlikely, it is a reasonable first approximation, even for relatively reactive nutrients like nitrate [Ensign and Doyle, 2006; Tank et al., 2008].

\section{Results and Discussion}

There was little evidence of bulk DOC decline between headwaters, tributaries, and basin mouth, based on comparison of land use relationships at each scale (Figure 2). In the headwaters, bulk DOC concentrations were strongly related to wetlands\% $\left(y=0.065+0.67 \times\right.$ wetland $\left.\%, R^{2}=0.71, p<0.001\right)$, as found in many previous studies [Buffam et al., 2007; Creed et al., 2003; Raymond and Hopkinson, 2003]. No other land uses attributes were significant. In the tributaries, the DOC relationship was not significant due to minimal range of wetland\% ( $p=0.26, n=6)$, but concentrations fall within those from the headwaters (Figure 2a). Regression parameters did not differ between headwaters and tributaries (ANCOVA, $p>0.05$ ). DOC concentration at the basin mouth, which has an intermediate wetland\%, was near those expected based on the headwater regression, $\sim 10 \mathrm{mg} \mathrm{L}^{-1}$. DOC concentration at the basin mouth was similar to those of large North American rivers for the given wetland\% [Hanley et al., 2013].

Similarly, SUVA $254, \mathrm{HPOA}, \mathrm{HPI}$, and TPIA were each highly correlated with wetland\% in the headwaters $\left(R^{2}=0.53-0.85, p<0.003\right)$, with similar though not significant relationships in the tributaries $\left(R^{2}=0.14-0.43\right.$, $p>0.09$ ), while the basin mouth fell within expectations for the intermediate wetland\% (Figures 2 and S1 in the supporting information). HPOA was the only relationship that was curvilinear (Figure 2b). The lack of clear change with river size suggests net consumption of each form or transformation from one form to another is relatively low through this river network, despite summer low flows when biotic and photoreactivity were expected to be high.

The behavior of DOC was similar to that of $\mathrm{Cl}^{-}$, which behaves conservatively in aquatic systems. $\mathrm{Cl}^{-}$in the headwaters was highly correlated to impervious $\%$ due to winter road salt inputs and accumulation in groundwater ( $y=3.8+8.9 \times$ impervious $\%, R^{2}=0.66, p<0.001$; Figure 2e). The tributary pattern for $\mathrm{Cl}^{-}$was not significantly different from that of the headwaters (ANCOVA $p>0.05$ ), and $\mathrm{Cl}^{-}$at the mouth fell within the expectation for basin level imperviousness.

In contrast, DIN appears to decline between the headwaters and basin mouth (Figure 2f). DIN concentration in headwaters was best predicted by the percent upstream anthropogenic land use, though the relationship was weaker than for DOC or $\mathrm{Cl}^{-}\left(-0.016+0.012 \times\right.$ developed $\left.\%, R^{2}=0.29, p=0.0034\right)$. DIN in tributaries 


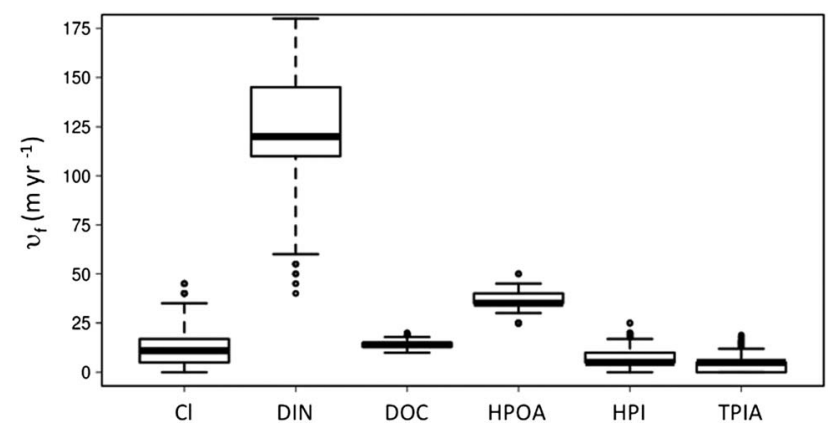

Figure 3. Uptake velocities calibrated for each constituent, given uncertainty in the loading relationships. Each bar represents box plots of the best fit uptake velocity across 3000 model runs. showed no relation with land use $(p=0.66)$ and was generally much lower (Figure 2), although the ANCOVA was not significant due to variability in the headwaters. DIN concentrations at the basin mouth were extremely low relative to some of the headwaters (Figure 2f). Sharp declines in DIN through the river system due to net removal are expected given the low flows and longer residence times (mean of 5 days during these flows) and relatively high reaction rates [Stewart et al., 2011; Wollheim et al., 2008]. Thus, we infer that net terrestrial carbon processing is considerably less than that for DIN.

The ANCOVA approach for detecting net DOC removal is relatively weak because of the inherent limitations of working in a single river network with nested streams. There are fewer tributaries than headwaters, and the tributaries have intermediate levels of land use since they mix multiple headwaters. There is only one basin mouth. As an alternative, we used the spatially distributed modeling approach to quantify net uptake velocities of each constituent.

Best fit, basin mean, net uptake velocities from the Monte Carlo simulations indicate that DIN was most reactive (median $v_{f}=120 \mathrm{~m} \mathrm{yr}^{-1}$, quartiles: $\left.110-145 \mathrm{~m} \mathrm{yr}^{-1}\right)$, followed by bulk DOC $\left(v_{f}=14 \mathrm{~m} \mathrm{yr}^{-1}\right.$; quartiles: 13-15 $\left.\mathrm{m} \mathrm{yr}^{-1}\right)$ and $\mathrm{Cl}^{-}\left(v_{f}=11 \mathrm{~m} \mathrm{yr}^{-1}\right.$; quartiles: $\left.5-17 \mathrm{~m} \mathrm{yr}^{-1}\right)$ (Figure 3). When bulk DOC was partitioned into HPOA, HPI, and TPIA, HPOA was relatively reactive $\left(v_{f}=37 \mathrm{~m} \mathrm{yr}^{-1}\right.$; quartiles: $\left.34-39 \mathrm{~m} \mathrm{yr}^{-1}\right)$, while HPI and TPIA were much less reactive $\left(v_{f} \sim 7\right.$ and $\left.4 \mathrm{~m} \mathrm{yr}^{-1}\right)$. Median whole network removal proportions are for DIN $=75 \%$, $\mathrm{Cl}=14 \%$, bulk DOC $=15 \%, \mathrm{HPOA}=34 \%, \mathrm{HPI}=8 \%, \mathrm{TPIA}=5 \%$ (Figure S2). Best fit $v_{f}^{\prime}$ s represent net uptake in the stream network, i.e., gross removal minus in-stream sources. In-stream sources could occur due to mineralization (for DIN), in-stream production of DOC (from primary producers or leaf litter), or transformation of one form of DOC to another (e.g., HPOA being converted to HPI or TPIA) [Cory et al., 2014]. Primary producers may be a source of in-stream DOC, but the character of the DOC did not change through the network (Figure S1) suggesting that if such sources occurred they are quickly removed. Our approach cannot address this rapid cycling of DOC.

We expect $\mathrm{Cl}^{-}$to be conservative in surface waters, so this $v_{f}$ should equal 0 . The apparent median $v_{f}>0$ for $\mathrm{Cl}^{-}$ suggests a bias in the $\mathrm{Cl}^{-}$loading model, possibly because the relationship, which was developed from headwaters, is not applicable to watershed areas draining directly to the main stem. Such errors may apply to the other constituents as well. Thus, we suggest that the $v_{f}$ estimated using this approach needs to be greater than that for $\mathrm{Cl}^{-}$to be considered $>0$. The best fit median $\mathrm{NO}_{3}-v_{f}\left(v_{f}=120 \mathrm{~m} \mathrm{yr}^{-1}\right)$ is much higher than that for $\mathrm{Cl}^{-}$ and is consistent with estimates from whole stream uptake experiments. Uptake velocities from whole reach ${ }^{15} \mathrm{NO}_{3}-\mathrm{N}$ tracer additions conducted in headwater streams in this basin $(n=9)$ ranged from 30 to $400 \mathrm{~m} \mathrm{yr}^{-1}$ for gross nitrate uptake (assimilation + denitrification), and from 9 to $103 \mathrm{~m} \mathrm{yr}^{-1}$ for denitrification alone [Mulholland et al., 2008]. An intermediate net $v_{f}$ is consistent with in-stream DIN regeneration [Brookshire et al., 2009] or higher denitrification rates in reaches dominated by wetlands [Wollheim et al., 2014].

HPOA appears to be less reactive (in terms of net removal) than nitrate, but more reactive than $\mathrm{Cl}^{-}, \mathrm{HPI}$, or TPIA. HPOA is dominated by humic substances, which are thought to be resistant to microbial degradation because of their aromatic ring structure [Wickland et al., 2007]. However, others have also found relatively high reactivity of humic substances in streams [Sleighter et al., 2014] possibly because of bound carbohydrates and amino acids [Volk et al., 1997]. HPOA also contains photoreactive forms of DOC and is highly correlated with SUVA $_{254}$ [Hanley et al., 2013; Spencer et al., 2012] (Figure S3). Thus, the HPOA net $v_{f}$ may reflect degradation due to sunlight [Cory et al., 2014; Mann et al., 2012]. Since HPOA is highly correlated with wetlands where anoxic soils occur, it is possible that a component of HPOA becomes microbially labile once water reaches oxygenated surface waters. Once oxygenated, precipitation with iron may also remove some HPOA [McKnight et al., 1992]. We cannot distinguish between these various fates with this network-scale analysis. 
HPI and TPIA $v_{f}$ was negligible in this analysis. These molecules are thought to be more reactive than HPOA [Wickland et al., 2007]. One explanation for the low net removal of HPI and TPIA is that the more labile components of these pools are removed rapidly as they first enter into surface waters and not sampled at the headwater stream sites (median upstream length $=1.6 \mathrm{~km}$ ), leaving the more refractory HPI and TPIA to flow through the rest of the river system. Wollheim et al. [2006] suggest that constituents with $v_{f}>1000 \mathrm{~m} \mathrm{yr}^{-1}$ would not be evident in the network during low flows. Many carbon monomers have $v_{f}$ this rapid [Newbold et al., 2006]. Thus, the more labile pools of HPI or TPIA compounds are not routed through the network and effectively not part of this analysis. An important question regarding the role of surface waters in the watershed carbon balance is whether such labile molecules are a large DOC transfer to surface waters.

Incomplete photooxidation of HPOA could result in transformation to the HPI and TPIA fractions. For example, Cory et al. [2014] noted a large proportion of photoreactions were incomplete in arctic waters, suggesting such transformations could be significant. This process would result in an underestimate of HPI or TPIA uptake, since we have not accounted for new inputs due to incomplete oxidation of HPOA. We are also not considering the rapid cycling of in situ DOC production. The relative lack of change in DOC character as indicated by HPOA\% and SUVA 254 (Figure S1), suggests that if in-stream production occurs, it is rapidly removed. DOC produced from autotrophs can be quickly respired relative to terrestrial DOC [Guillemette et al., 2013], so is less likely to be transported far downstream.

The different DOC fractions used in this study behaved differently, and model fits were improved relative to using bulk DOC alone (Figure 4). Finer-scale patterns along the main stem further support net removal of HPOA and conservative HPI and TPIA fractions. The best model fit for bulk DOC could not match observed concentration patterns along the basin profile, overestimating in the middle reaches, and underestimating in the lower reaches (Figure 4b). However, when the DOC pool is resolved into HPOA, HPI, and TPIA, predicted patterns better match observations (Figures $4 \mathrm{c}$ and $4 \mathrm{~d}$ ). The 35 to $20 \mathrm{~km}$ section of the main stem has lower wetland abundance, so moderate reaction rates would cause a net concentration decline (as seen in HPOA). The 15 to $10 \mathrm{~km}$ section contains large wetland-dominated areas (Figures 1 and 4a), which should cause increases particularly in HPOA due to the nonlinear relationship (Figure 2b), consistent with the patterns we predict (Figure 4). These findings clearly point to the need to partition bulk DOC into different fractions as highlighted in a number of recent studies [Cory et al., 2014; Cory and Kaplan, 2012; Kaplan et al., 2008; Sleighter et al., 2014].

The net uptake velocities derived from this whole network-scale approach are much lower than those measured during carbon addition experiments at whole stream reach scales. Previous studies indicate a wide range of uptake velocities, ranging from $>1000 \mathrm{~m} \mathrm{yr}^{-1}$ for labile material such as arabinose or acetate [Johnson and Tank, 2009; Newbold et al., 2006], $>200 \mathrm{~m} \mathrm{yr}^{-1}$ for leaf leachate [Bernhardt and McDowell, 2008], and $>80 \mathrm{~m} \mathrm{yr}^{-1}$ using ${ }^{13} \mathrm{C}$ labeled poplar leaf leachate [Wiegner et al., 2005]. As discussed above, we may be underestimating terrestrial carbon pools that are highly reactive and do not appear in our headwater samples. Others have found highly labile DOC generally represents a small component in streams [Kaplan et al., 2008]. Bioreactor studies also indicate DOC can be highly reactive [Cory and Kaplan, 2012; Sleighter et al., 2014]. Bioreactor studies have higher contact time with sediments than is experienced by flowing surface waters [Cory and Kaplan, 2012]. Flowing surface waters must first exchange into hyporheic sediments where DOC consumption is high. Our calibrated uptake velocity effectively integrates the role of hyporheic exchange [see Stewart et al., 2011]. Nevertheless, our findings suggest that in this system, most DOC derived from terrestrial ecosystems was not removed by the stream network. Understanding the abundance of different forms entering streams, and their individual reaction rates [Kaplan et al., 2008] would help interpret these network-scale findings.

We suggest synoptic measurements of DOC character throughout basins are helpful to constrain net removal of terrestrial DOC by river systems. Additional studies incorporating DOC character are needed during a range of conditions to better understand the fate of terrestrial DOC. For example, we hypothesize that networkscale DOC uptake velocities are higher during higher-flow conditions because more labile DOC reaches surface waters when soil organic matter sources bypass mineral soils [Inamdar et al., 2008]. The proportion of terrestrial DOC removed in the river network at high flow will also be a function of changing hydraulic loads [Wollheim et al., 2006, 2008]. It would be useful to conduct similar studies using more highly resolved DOC partitioning approaches [Cory and Kaplan, 2012]. A limitation of synoptic techniques is that they require 

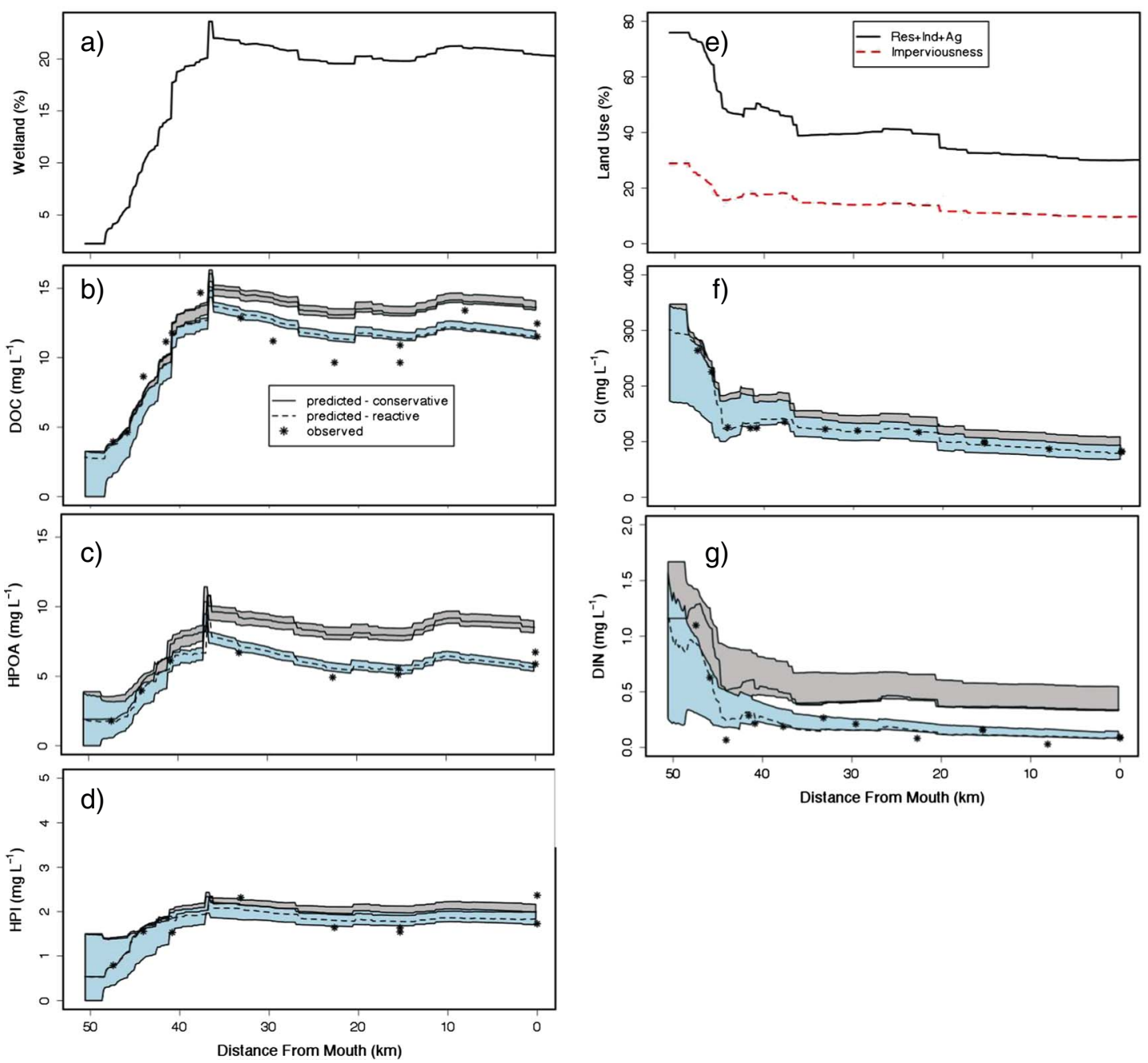

Figure 4. Basin profiles along surface water flow path from furthest headwater to basin mouth showing (a) upstream wetland\%, and observed, model predicted based on conservative behavior and model predicted based on reactive behavior for (b) bulk DOC, (c) HPOA, (d) HPI, (e) upstream impervious\% and human\%, (f) $\mathrm{Cl}^{-}$, and (g) DIN. Shaded areas represent the 5th and 95th percentile confidence intervals for conservative mixing (gray) and reactivity (blue) based on the Monte Carlo loading analysis. 
reactive fraction, and we cannot distinguish whether this is due to microbial, photochemical, or physical processes. Our results are consistent with other studies that suggest that DOC in river systems is relatively conservative across a range of watershed sizes, unless aquatic residence times are long, as in lake or reservoir-dominated watersheds [Hanley et al., 2013; Agren et al., 2014]. However, these findings are in contrast to many whole stream reach studies of DOC reactivity that suggest rapid uptake. Our study cannot rule out the removal of extremely labile fractions immediately as they enter the river network. The ability of global aquatic systems to respire terrestrial DOC will depend on the timing, distribution, and form of DOC loading to the network, the distribution of residence times, and DOC reaction rates of different forms along the aquatic continuum. Dynamic, time varying models, parameterized with field measurements of different DOC forms across a range of conditions will help further understand the aquatic carbon balance.

\section{Acknowledgments}

This work was supported by the National Science Foundation NSF-OCE-1058747 and OCE-1238212 (Plum Island LTER) and National Aeronautics and Space Administration grant NNX09AU89G. Data used in this manuscript are available upon request and via the Plum Island Long Term Ecological Research projects web site. We also thank Richard Carey and Sophie Burke for their help in the field, and four anonymous reviewers for their comments which greatly improved the paper. The use of brand names is for identification purposes only and does not constitute endorsement by the U.S. Geological Survey.

The Editor thanks four anonymous reviewers for their assistance in evaluating this paper.

\section{References}

Agren, A., I. Buffam, D. Cooper, T. Tiwari, C. Evans, and H. Laudon (2014), Can the heterogeneity in stream dissolved organic carbon be explained by contributing landscape elements?, Biogeosciences, 11, 1199-1213, doi:10.5194/bg-1111-1199-2014.

Aiken, G. R., D. M. McKnight, K. A. Thorn, and E. M. Thurman (1992), Isolation of hydrophilic acids from water using macroporous resins, Org. Geochem., 18, 567-573.

AufdenKampe, A., E. Mayorga, P. A. Raymond, J. M. Melack, S. C. Doney, S. R. Alin, R. E. Aalto, and K. Yoo (2011), Riverine coupling of biogeochemical cycles between land, oceans, and atmosphere, Front. Ecol. Environ., 9, 53-60, doi:10.1890/100014.

Battin, T. J., L. A. Kaplan, S. Findlay, C. S. Hopkinson, E. Marti, A. I. Packman, J. D. Newbold, and F. Sabater (2008), Biophysical controls on organic carbon fluxes in fluvial networks, Nat. Geosci., 1(2), 95-100.

Bernhardt, E. S., and W. H. McDowell (2008), Twenty years apart: Comparisons of DOM uptake during leaf leachate releases to Hubbard Brook Valley streams 1979 versus 2000, J. Geophys. Res., 113, G03032, doi:10.1029/2007JG000618.

Bernot, M. J., et al. (2010), Inter-regional comparison of land-use effects on stream metabolism, Freshwater Biol., 55, 1874-1890.

Brookshire, E. N., H. M. Valett, and S. Gerber (2009), Maintenance of terrestrial nutrient loss signatures during in-stream transport, Ecology, 90(2), 293-299.

Buffam, l., H. Laudon, J. Temnerud, C. M. Morth, and K. Bishop (2007), Landscape-scale variability of acidity and dissolved organic carbon during spring flood in a boreal stream network, J. Geophys. Res., 112, G01022, doi:10.1029/2006JG000218.

Butman, D., P. A. Raymond, K. Butler, and G. R. Aiken (2012), Relationships between 14C and the molecular quality of dissolved organic carbon in rivers draining to the coast from the conterminous United States, Global Biogeochem. Cycles, 26, GB4014, doi:10.1029/2012GB004.

Cole, J. J., and N. F. Caraco (2001), Carbon in catchments: Connecting terrestrial carbon losses with aquatic metabolism, Mar. Freshwater Resour., 52, 101-110.

Cole, J. J., et al. (2007), Plumbing the global carbon cycle: Integrating inland waters into the terrestrial carbon budget, Ecosystems, 10 , $171-184$.

Cory, R. M., and L. A. Kaplan (2012), Biological lability of streamwater fluorescent dissolved organic matter, Limnol. Oceanogr., 57, 1347-1360.

Cory, R. M., C. P. Ward, B. C. Crump, and G. W. Kling (2014), Sunlight controls water column processing of carbon in arctic freshwater, Science, 345, 925-928.

Creed, I. F., S. E. Sanford, F. D. Beall, L. A. Molot, and P. J. Dillon (2003), Cryptic wetlands: Integrating hidden wetlands in regression models of the export of dissolved organic carbon from forested landscapes, Hydrol. Processes, 17, 3629-3648.

Ensign, S. H., and M. W. Doyle (2006), Nutrient spiraling in streams and river networks, J. Geophys. Res., 111, G04009, doi:10.1029/ 2005JG000114.

Finlay, J. C. (2002), Controls of streamwater dissolved inorganic carbon dynamics in a forested watershed, Biogeochemistry, 62, $231-253$.

Guillemette, F., S. L. McCallister, and P. A. del Giorgio (2013), Differentiating the degradation dynamics of algal and terrestrial carbon within complex natural dissolved organic carbon in temperate lakes, J. Geophys. Res. Biogeosci., 118, 963-973, doi:10.1002/jgrg.20077.

Hanley, K., W. M. Wollheim, J. Salisbury, T. Huntington, and G. R. Aiken (2013), Controls on dissolved organic carbon quantity and chemical character in temperate rivers of North America, Global Biogeochem. Cycles, 27, 492-504, doi:10.1002/gbc.20044.

Inamdar, S., J. Rupp, and M. Mitchell (2008), Differences in dissolved organic carbon and nitrogen responses to storm-event and ground-water conditions in a forested, glaciated watershed in Western New York, J. Am. Water Resour. Assoc., 44(6), 1458-1473.

Johnson, L., and J. L. Tank (2009), Diel fluctuations in dissolved organic carbon and nitrogen uptake in six Wyoming streams, J. N. Am. Benthol. Soc., 28, 694-708.

Johnson, M. S., J. Lehmann, S. J. Riha, A. V. Krusche, J. E. Richey, J. P. Ometto, and E. G. Couto (2008), $\mathrm{CO}_{2}$ efflux from Amazonian headwater streams represent signficiant fate for deep soil respiration, Geophys. Res. Lett., 35, L17401, doi:10.1029/2008GL034619.

Kaplan, L. A., T. N. Wiegner, J. D. Newbold, P. H. Ostrom, and H. Gandhi (2008), Untangling the complex issue of dissolved organic carbon uptake: A stable isotope approach, Freshwater Biol., 53, 855-864, doi:10.1111/j.1365-2427.2007.01941.x.

Kaushal, S. S., K. Delaney-Newcomb, S. E. G. Findlay, T. A. Newcomer, S. Duan, M. J. Pennino, G. M. Sivirichi, A. M. Sides-Raley, M. R. Walbridge, and K. T. Belt (2014), Longitudinal patterns in carbon and nitrogen fluxes and stream metabolism along an urban watershed continuum, Biogeochemistry, doi:10.1007/s10533-014-9979-9.

Mann, P. J., A. Davydiva, N. Zimov, R. Spencer, S. Davydiv, E. Bulygina, S. Zimov, and R. M. Holmes (2012), Controls on the composition and lability of dissolved organic matter in Siberia's Kolyma River basin, J. Geophys. Res., 117, G01028, doi:10.1029/2011JG001798.

McKnight, D. M., K. E. Bencala, G. W. Zellweger, G. R. Aiken, G. L. Feder, and K. A. Thorn (1992), Sorption of dissolved organic carbon by hydrous aluminum and iron oxides occurring at the confluence of Deer Creek with the Snake River, Summit County, Colorado, Environ. Sci. Technol., 26(7), 1388-1396.

Mulholland, P. J., et al. (2008), Stream denitrification across biomes and its response to anthropogenic nitrate loading, Nature, 452(7184), 202-205.

Newbold, J. D., T. L. Both, L. A. Kaplan, C. L. Dow, J. K. Jackson, A. AufdenKampe, L. A. Martin, D. J. Van Horn, and A. A. de Long (2006), Uptake of nutrients and organic $C$ in streams in New York City drinking-water-supply watersheds, J. N. Am. Benthol. Soc., 25, 998-1017.

R Core Team (2014), R: A language and environment for statistical computing, R Foundation for Statistical Computing, Vienna, Austria. [Available at http://www.R-project.org/.] 
Raymond, P. A., and C. S. Hopkinson (2003), Ecosystem modulation of dissolved carbon age in a temperate marsh-dominated estuary, Ecosystems, 6, 694-705.

Richey, J. E., J. Melack, A. AufdenKampe, V. Ballester, and L. Hess (2002), Outgassing from Amazonian rivers and wetlands as a large tropical source of atmospheric $\mathrm{CO}_{2}$, Nature, 416, 617-619.

Sleighter, R., R. M. Cory, L. A. Kaplan, H. Abdulla, and P. G. Hatcher (2014), A coupled geochemical and biogeochemical approach to characterize the bioreactivity of dissolved organic matter from a headwater stream, J. Geophys. Res. Biogeosci., 119, 1520-1537, doi:10.1002/2013JG002600.

Spencer, R. G., K. D. Butler, and G. R. Aiken (2012), Dissolved organic carbon and chromophoric dissolved organic matter properties of rivers in the USA, J. Geophys. Res., 117, G03001, doi:10.1029/2011JG001928.

Stewart, R. J., W. M. Wollheim, M. Gooseff, M. A. Briggs, J. M. Jacobs, B. J. Peterson, and C. S. Hopkinson (2011), Separation of river networkscale nitrogen removal among main channel and two transient storage compartments, Water Resour. Res., 47, W00J10, doi:10.1029/ 2010 WR009896.

Tank, J. L., E. J. Rosi-Marshall, M. A. Baker, and R. O. Hall (2008), Are rivers just big streams? A pulse method to quantify nitrogen demand in a large river, Ecology, 89, 2935-2945.

Tiwari, T., H. Laudon, K. Beven, and A. Agren (2014), Downstream changes in DOC: Inferring contributions in the face of model uncertainties, Water Resour. Res., 50, 514-525, doi:10.1002/2013WR014275.

Volk, C. J., C. B. Volk, and L. A. Kaplan (1997), Chemical composition of biodegradable dissolved organic matter in streamwater, Limnol. Oceanogr., 42, 39-44.

Weishaar, J. L., G. R. Aiken, B. A. Bergamaschi, M. S. Fram, R. Fujii, and K. Mopper (2003), Evaluation of specific ultraviolet absorbance as an indicator of the chemical composition and reactivity of dissolved organic carbon, Environ. Sci. Technol., 37, 4702-4708.

Wickland, K., J. C. Neff, and G. R. Aiken (2007), Dissolved organic carbon in Alaskan boreal forest: Sources, chemical characteristics, and biodegradability, Ecosystems, doi:10.1007/s10021-007-9101-4.

Wiegner, T. N., L. A. Kaplan, J. D. Newbold, and P. H. Ostrom (2005), Contribution of dissolved organic C to stream metabolism: A mesocosm study using C-13-enriched tree-tissue leachate, J. N. Am. Benthol. Soc., 24(1), $48-67$.

Wollheim, W. M., C. J. Vorosmarty, B. J. Peterson, S. P. Seitzinger, and C. S. Hopkinson (2006), Relationship between river size and nutrient removal, Geophys. Res. Lett., 33, L06410, doi:10.1029/2006GL025845.

Wollheim, W., B. Peterson, C. Vorosmarty, C. Hopkinson, and S. Thomas (2008), Dynamics of N removal over annual time scales in a suburban river network, J. Geophys. Res., 113, G03038, doi:10.1029/2007JG000660.

Wollheim, W., T. K. Harms, B. J. Peterson, K. Morkesk, C. Hopkinson, R. Stewart, M. Gooseff, and M. A. Briggs (2014), Nitrate uptake dynamics of surface transient storage in stream channels and fluvial wetlands, Biogeochemistry, doi:10.1007/s10533-014-9993-y. 